\title{
Changes in soil organic matter composition after Scots pine afforestation in a native European beech forest revealed by analytical pyrolysis (Py-GC/MS)
}

\author{
Antonio Girona-García a,b,* David Badía-Villas ${ }^{\text {b }}$, Nicasio T. Jiménez-Morillo ${ }^{\text {c,d }}$, José A. González-Pérez ${ }^{\text {e }}$ \\ a Centre for Environmental and Marine Studies (CESAM), Department of Environment and Planning, University of Aveiro, $3810-193$ Aveiro, Portugal

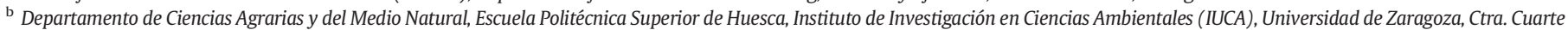 \\ s/n, 22071 Huesca, Spain \\ c Departamento de Fitotecnia, Escola de Ciências e Tecnologia, ICAAM, Universidade de Évora, Núcleo da Mitra, Ap. 94, 7006-554 Évora, Portugal \\ ${ }^{d}$ HERCULES Laboratory, Universidade de Évora, Palácio do Vimioso, 7000-089 Évora, Portugal \\ e Instituto de Recursos Naturales y Agrobiología de Sevilla (IRNAS-CSIC), MOSS Gr. Avda. Reina Mercedes 10, 41012 Sevilla, Spain
}

\section{H I G H L I G H T S}

- A total of 128 pyrolysis compounds were detected in the soil organic matter (SOM).

- Polysaccharides in Bhs and BC under pine may indicate migration of complexed forms.

- Natural beech forest alkane series point to higher SOM stabilization.

- Biomarkers in pine show permanence of beech-derived SOM 100 yrs. after afforestation.

\section{G R A P H I C A L A B S T R A C T}

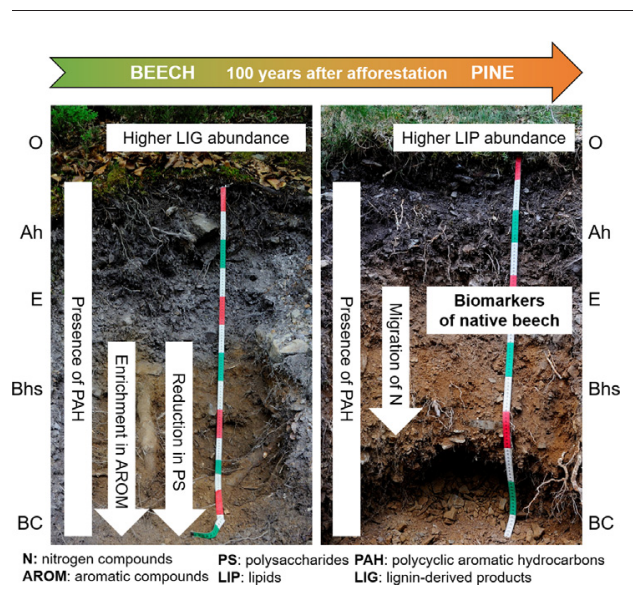

\begin{abstract}
A B S T R A C T
The introduction of coniferous species in former deciduous forests may exert changes in soil organic matter, particularly in its molecular composition. In this work, pyrolysis-gas chromatography-mass spectrometry was used to study changes in SOM quality related to the centennial afforestation of Scots pine in an area formerly covered by European beech forest in the NE-flank of the Moncayo Natural Park (NE-Spain). For each soil profile three organic layers (fresh litter, fragmented litter and humified litter) and mineral soil horizons (Ah, E, Bhs and C) were studied. A total of 128 compounds were identified in the pyrograms, and composition differences were detected among the organic and mineral soil layers as well as between soils under beech and pine, for the main compound classes: nitrogen compounds, aromatics, lignin methoxyphenols, polycyclic aromatic hydrocarbons, lipids and polysaccharide-derived moieties. Such chemical differences were found to be derived from the biomass composition of the predominant vegetation type that was incorporated into the soil and from its progression into the soil profile. The analysis of the distribution of alkanes indicated higher SOM stabilization in the native beech
\end{abstract}

\section{Keywords:}

Biogeochemistry

Biomarkers

Alkanes

Lignin

\footnotetext{
* Corresponding author at: Centre for Environmental and Marine Studies (CESAM), Department of Environment and Planning, University of Aveiro, 3810-193 Aveiro, Portugal. E-mail address: antoniogironagarcia@ua.pt (A. Girona-García).
} 
Methoxyphenols Litter layers forest soil. The signal of beech biomarkers (long chain $n$-alkanes $C_{31}-C_{33}$ ) found in the pine $E$ horizon indicates the permanence of SOM derived from the natural forest ca. 100 years after the afforestation.

(C) 2019 Elsevier B.V. All rights reserved.

\section{Introduction}

Forest soils play an important role in biogeochemical cycles since they store large amounts of C and N (IPCC, 2014; Marty et al., 2011). The stocks of $\mathrm{C}$ and $\mathrm{N}$ can be affected not only by climate change but also by shifts in land use such as the replacement of tree species (Leuschner et al., 2013). The processes involved in the soil-vegetation interaction are complex; vegetation influences the soil, among other factors, by the diverse composition of the produced litter, which together will influence the chemical composition of the soil organic matter (SOM) (Binkley, 1995). For this reason, it is expected that changes in the vegetation cover will result in SOM contributions of different nature and therefore, contrasted chemical composition.

In the late 19th century, as a consequence of uncontrolled logging for charcoal production, the population of native European beech (Fagus sylvatica) in the Moncayo Natural Park (NE-Spain) was reduced to near disappearance. This also increased soil erosion (García Manrique, 1960 ) and in order to stop this phenomenon in the areas where the beech forests were decimated, afforestation of Scots pine (Pinus sylvestris) was conducted in the first decades of the 20th century. Consequently, shifts in vegetation such as those that were undertaken in that area ca. 100 years ago may exert remarkable changes in SOM composition. Such changes have been previously detected in the Moncayo Natural Park in a study by Girona-García et al. (2018a), which found differences in SOM C and N stable isotope composition between the natural beech and the afforested pine forests.

Organic matter is considered to be the most essential constituent of soils because it virtually influences all physical, chemical and biological properties of soil (Weil and Brady, 2017). Litter deposition is usually the main source of SOM, so changes in the amount and composition of litter will influence the complexity and stability of the SOM once incorporated into the soil (Kögel-Knabner et al., 2008). For this reason, it is important to study how forest management activities, such as afforestation, can influence the composition of SOM, especially when broad-leaved forests are replaced by coniferous species, whose litter is more difficult to decompose, resulting in litter accumulation on the topsoil (Labaz et al., 2014; Badia-Villas and Girona-García, 2018; Girona-García et al., 2018a, 2018b).

Pyrolysis-gas chromatography-mass spectrometry (Py-GC/MS) analysis is a technique widely used for the structural characterization of SOM (González-Pérez et al., 2012; Rumpel et al., 2012; Derenne and Quénéa, 2015). It is a powerful tool that allows the separation and identification of the SOM constituents without prior chemical treatment (Moldoveanu, 1998; González-Pérez et al., 2007). Py-GC/MS generates a fingerprint that allows the quantification of the relative abundance of the different chemical compounds that constitute the SOM (White et al., 2004; González-Pérez et al., 2007; Almendros et al., 2018). The main compounds produced by pyrolysis are of known biogenic origin; for example, by pyrolysis, polysaccharides produce anhydrosugars, lignin originates methoxyphenols, proteins result in certain nitrogen compounds, and lipids produce alkanes, alkenes, waxes, terpenes, and steranes (González-Vila et al., 2009; De la Rosa et al., 2012). The detailed study of the results obtained by Py-GC/MS allows determining the sources and contributions of SOM in the soil, evaluate the preservation of certain biogenic materials and the selective decomposition of others that come from vegetation or that are transformed into the soil (González-Vila et al., 1999; González-Pérez et al., 2003; Almendros et al., 2018). Among the compounds originating from pyrolysis, molecular markers such as aliphatic, aromatic and heteroaromatic compounds can be found, which are related to shifts in land use and/ or vegetation cover as well as perturbances such as wildfires or pollutant discharges (Buco et al., 2004; Faria et al., 2015; Miralles et al., 2015; Santana et al., 2015; Jiménez-Morillo et al., 2016).

The aim of this study was to analyze by Py-GC/MS the qualitative changes in SOM related to the afforestation of Scots pine in areas formerly populated by native European beech forests, ca. 100 years after the afforestation was conducted. We hypothesized that the different nature of the litter produced by both species will result in different decomposition paths of SOM and will allow the depth to which the SOM of the introduced species has been incorporated into the soil to be traced.

\section{Materials and methods}

\subsection{Area of study}

The study site was located in the NE flank of the Moncayo Massif (Iberian Range, NE-Spain) at an elevation between 1360 and 1475 m a.s.l., where natural European beech (Fagus sylvatica) and afforested Scots pine (Pinus sylvestris) forests can be found. The understory of the beech forest mainly consists of Vaccinum myrtillus L. and Erica arborea L. whereas in the pine forest, Ilex aquifolium L. and Deschampsia flexuosa L. can also be observed. The mean annual rainfall is $1060 \mathrm{~mm}$ and the mean annual temperature is $9.2^{\circ} \mathrm{C}$ (Ibarra and Echeverría, 2004; Martínez del Castillo et al., 2012). Soils were developed over Lower Triassic quartzitic sandstones and showed a series of common properties such as high stoniness, extreme to strong acidity, low base content, high SOM content, and sandy loam or loamy textures (Badia et al., 2016; Girona-García et al., 2018b). The general physical and chemical properties of the soil profiles are provided in Table 1. The studied soil profiles were classified as Skeletic Umbric Albic Podzol (Loamic) (IUSS WRB, 2014) and Typic Haplorthod (SSS, 2014).

\subsection{Sampling and sample preparation}

Sampling was conducted in September 2014. Two sampling sites (Fig. 1), one in the natural beech forest $\left(41^{\circ} 47^{\prime} 32.15^{\prime \prime} \mathrm{N} ; 1^{\circ} 48^{\prime}\right.$ $\left.24.89^{\prime \prime} \mathrm{W}\right)$ and one in the afforested pine forest $\left(41^{\circ} 47^{\prime} 01.85^{\prime \prime} \mathrm{N} ; 1^{\circ}\right.$

Table 1

General chemical and physical properties of the studied soil profiles.

\begin{tabular}{|c|c|c|c|c|c|c|c|c|}
\hline \multirow{2}{*}{$\frac{\text { Soil profile }}{\text { Horizon }}$} & \multicolumn{4}{|c|}{ European beech } & \multicolumn{4}{|c|}{ Scots pine } \\
\hline & $\mathrm{Ah}$ & $\mathrm{E}$ & Bhs & $\mathrm{BC}$ & $\mathrm{Ah}$ & $\mathrm{E}$ & Bhs & $\mathrm{BC}$ \\
\hline Depth (cm) & $0-25$ & $25-55$ & $55-75$ & $75-100$ & $0-30$ & $30-60$ & $60-90$ & $90-120$ \\
\hline $\mathrm{pH}\left(\mathrm{H}_{2} \mathrm{O}, 1: 2.5\right)$ & 4.0 & 4.2 & 4.9 & 4.9 & 4.7 & 4.6 & 5.0 & 5.3 \\
\hline $\mathrm{pH}(\mathrm{KCl}, 1: 2.5)$ & 2.9 & 3.2 & 4.2 & 4.3 & 3.7 & 3.3 & 3.9 & 4.3 \\
\hline \multicolumn{9}{|l|}{$\mathrm{CEC}(\mathrm{cmol}+$} \\
\hline $\begin{array}{l}\text { Total Organic C } \\
\left(\mathrm{g} \mathrm{kg}^{-1}\right)\end{array}$ & 61.1 & 27 & 40.9 & 40.5 & 92 & 35 & 42 & 38 \\
\hline Total N $\left(\mathrm{g} \mathrm{kg}^{-1}\right)$ & 5.6 & 4.7 & 5.00 & 4.9 & 7.6 & 4.9 & $\begin{array}{l}42 \\
5.5\end{array}$ & 4.9 \\
\hline $\mathrm{C} / \mathrm{N}$ & 11 & 5.7 & 8.2 & 8.3 & 12.1 & 7.0 & 7.6 & 7.8 \\
\hline Clay $\left(\mathrm{g} \mathrm{kg}^{-1}\right)$ & 117 & 71 & 159 & 113 & 215 & 170 & 234 & 81.2 \\
\hline Silt $\left(\mathrm{g} \mathrm{kg}^{-1}\right)$ & 276 & 309 & 291 & 328 & 329 & 406 & 314 & 447 \\
\hline Sand $\left(\mathrm{g} \mathrm{kg}^{-1}\right)$ & 607 & 620 & 550 & 559 & 456 & 424 & 452 & 471 \\
\hline Textural class & \multicolumn{4}{|c|}{ Sandy loam } & \multicolumn{4}{|c|}{ Loam } \\
\hline WHC $\left(\mathrm{g} \mathrm{kg}^{-1}\right)$ & 175 & 141 & 242 & 218 & 217 & 160 & 190 & n.d. \\
\hline $\begin{array}{l}\text { Coarse fraction } \\
\left(\mathrm{g} \mathrm{kg}^{-1}\right)\end{array}$ & 809 & 831 & 725 & 951 & 642 & 852 & 732 & 568 \\
\hline
\end{tabular}

n.d.: not determined. 


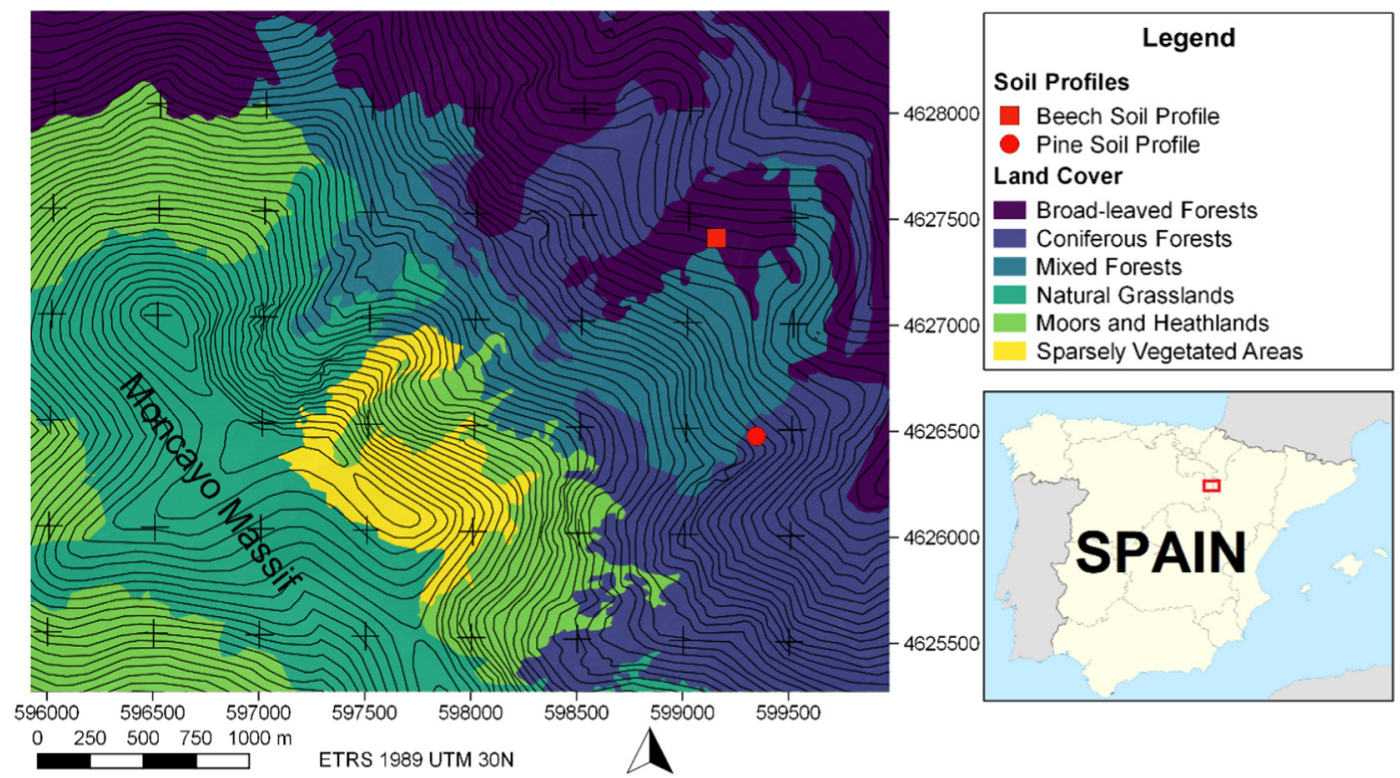

Fig. 1. Location of the sampling sites in the Moncayo Natural Park.

$48^{\prime} 16.66^{\prime \prime} \mathrm{W}$ ) were selected based on the similarity of the soil horizon distribution, elevation, and geomorphological characteristics. In each of the sampling sites, one soil profile in each forest type was selected and a substantial and representative amount of the organic layers and the mineral horizons was sampled. The organic layers were separated in fresh litter (OL), fragmented litter (OF) and humified litter $(\mathrm{OH})$ and the mineral horizons were classified as Ah, E, Bhs and BC (Fig. 2).

All samples were air-dried until constant weight and the mineral samples were sieved through a $2 \mathrm{~mm}$ mesh. Prior to analysis, all samples were ground to fine powder and homogenized using an agate mortar aided with liquid nitrogen.

\section{Beech soil profile}

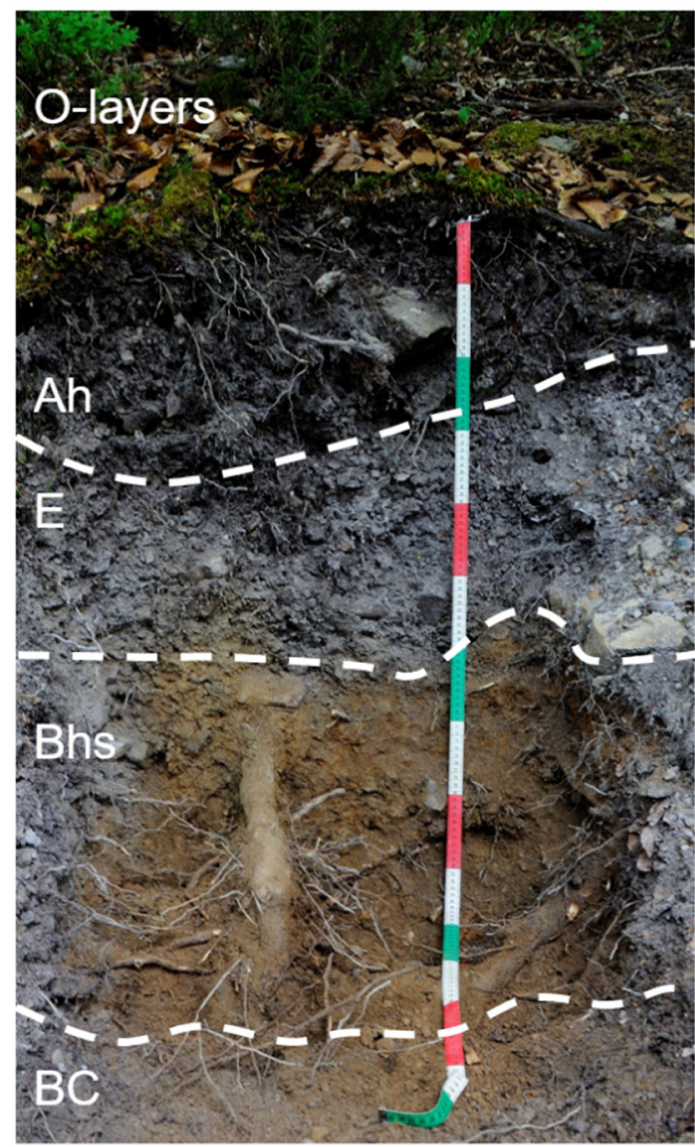

\section{Pine soil profile}

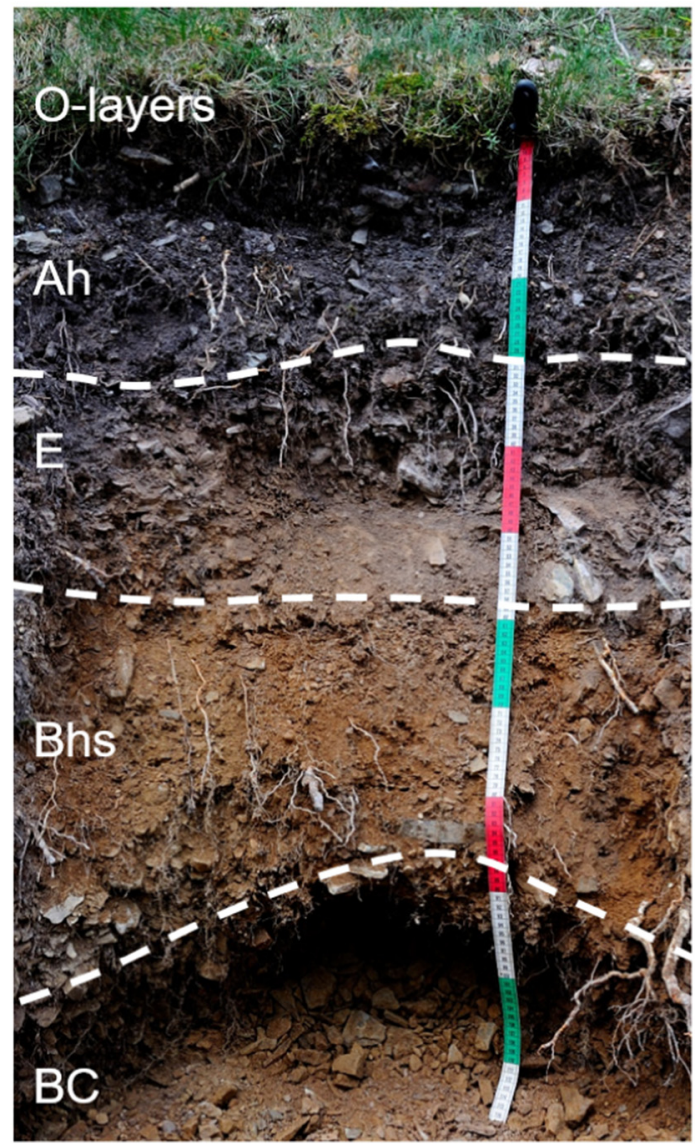

Fig. 2. Sampled soil profiles in the native beech (left) and afforested pine (right) forests. 


\subsection{Pyrolysis-gas chromatography-mass spectrometry analysis}

Pyrolysis-gas chromatography-mass spectrometry (Py-GC/MS) analysis was performed for SOM characterization on both organic and mineral horizons using a double-shot pyrolyzer (Frontier Laboratories, 2020i) attached to a GC/MS system (Agilent 6890N). The samples were capsuled and introduced in the micro furnace previously heated to $500{ }^{\circ} \mathrm{C}$ for $1 \mathrm{~min}$. Then the pyrolysis products were automatically injected into the GC/MS for analysis. The gas chromatograph was equipped with a low polar capillary column (Agilent J\&W HP-5 ms UI; $30 \mathrm{~m} \times 250 \mu \mathrm{m} \times 0.25 \mu \mathrm{m}$ ). The oven temperature was held at $50{ }^{\circ} \mathrm{C}$ for $1 \mathrm{~min}$ and then increased to $100{ }^{\circ} \mathrm{C}$ at 30 ${ }^{\circ} \mathrm{C}$ min $^{-1}$, from $100{ }^{\circ} \mathrm{C}$ to $300{ }^{\circ} \mathrm{C}$ at $10{ }^{\circ} \mathrm{C} \mathrm{min}^{-1}$, and stabilized at $300{ }^{\circ} \mathrm{C}$ for $10 \mathrm{~min}$. Helium was used as the carrier gas, at a constant rate of $1 \mathrm{~mL} \mathrm{~min}^{-1}$ and the total analysis time was $32 \mathrm{~min}$. The detector consisted of a mass selective detector (Agilent 5973 Technologies $5973 \mathrm{~N}$ ) and mass spectra were acquired at ionization energy of $70 \mathrm{eV}$.

\subsection{Data analysis}

The collection and processing of data was performed using the Agilent ChemStation Data Analysis software. Compound assignment was achieved by single-ion monitoring (SIM) for the major homologous series and by comparison with published data reported in the literature or stored in the digital NIST 14 (Maryland, USA) and Wiley 7 (Weinheim, Germany) libraries. This procedure allowed the identification of the main organic compounds in the samples as well as a semiquantitative assessment in terms of relative abundances of compounds in the pyrolysates. The relative abundance of the pyrolysis products was calculated by normalizing the peak areas of each individual compound to the total area for all the peaks of the detected products. The identified compounds were grouped according to their probable origin in the following families: nitrogen compounds, aromatic compounds, polysaccharides, lignin-derived products, polycyclic aromatic hydrocarbons and lipids. In this way, the summation of the normalized peak areas of the individual compounds for each family allowed their relative abundances to be calculated.

\section{Results and discussion}

\subsection{Soil organic matter composition revealed by Py-GC/MS}

Well-resolved chromatograms were obtained for both organic and mineral soil layers with a grand total of 128 different compounds detected; including 96 under beech and 89 under pine (Supplementary Material).

In the soils developed under both forest types, the N-derived compounds showed a similar distribution pattern with depth (Fig. 3), increasing from the OL to Ah horizons (6.47 to 13.3\% and 5.68 to $19.0 \%$ in beech and pine, respectively) and decreasing in the E horizons down to 8.12 and $11.6 \%$ for beech and pine, respectively. The increase in $\mathrm{N}$-derived compounds in the Ah horizon could be explained by a higher SOM degradation once incorporated into the mineral soil (Vancampenhout et al., 2009). On the other hand, the decrease detected in the $\mathrm{E}$ mineral horizon could be a consequence of the migration of $\mathrm{N}$ compounds towards deeper soil layers. This is a probable explanation for the pine profile, since a higher relative abundance of $\mathrm{N}$-compounds was observed in the Bhs and BC horizons compared to the E. However, this effect was not detected in the beech profile, as no $\mathrm{N}$ compounds were identified in the Bhs and $\mathrm{BC}$ horizons.

The relative abundance of lipids (Fig. 3) in the organic horizons released by pyrolysis was higher in the pine profile (8.40-14.9\%) than in the beech profile (1.80-2.31\%). Lipid preservation in the organic layers of the pine profile may indicate differences in its biomass composition compared to the organic layers of the beech profile. It has been previously observed that this type of compound is present and abundant in the litter and in the suberin of the barks of coniferous trees (Derenne and Quénéa, 2015). Another probable explanation for this process could be the delay in microbial degradation related to low-quality (high C/N ratio) SOM contributions (Vancampenhout et al., 2009). On the other hand, no differences were detected between forest types for the mineral horizons except for the $\mathrm{BC}$ horizons, where the relative abundance of lipids was notably higher in the beech profile $(30.7 \%)$ than in the pine profile (2.02\%). This can be associated with root contributions at that depth.

The relative abundance of aromatic compounds in the organic layers showed an opposing trend in both soil profiles (Fig. 3). In the beech
Beech Soil Profile

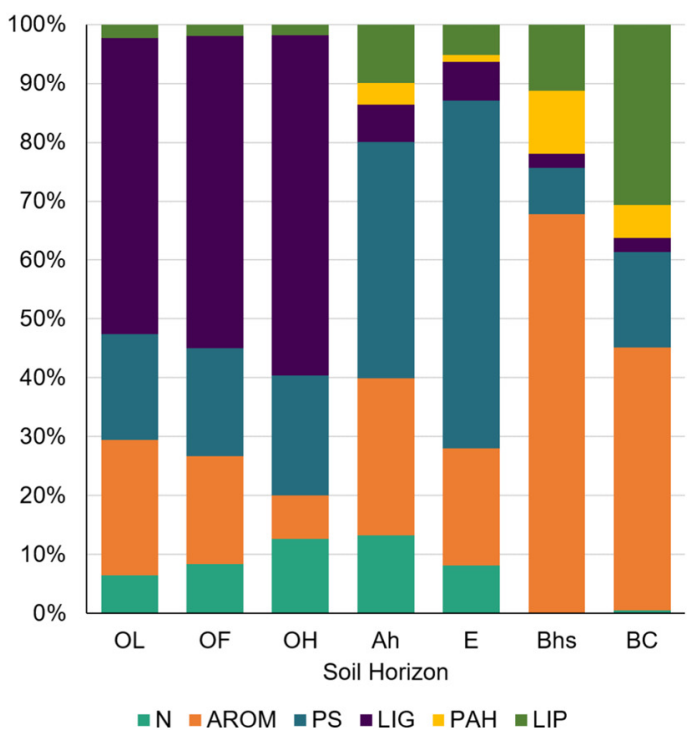

Pine Soil Profile

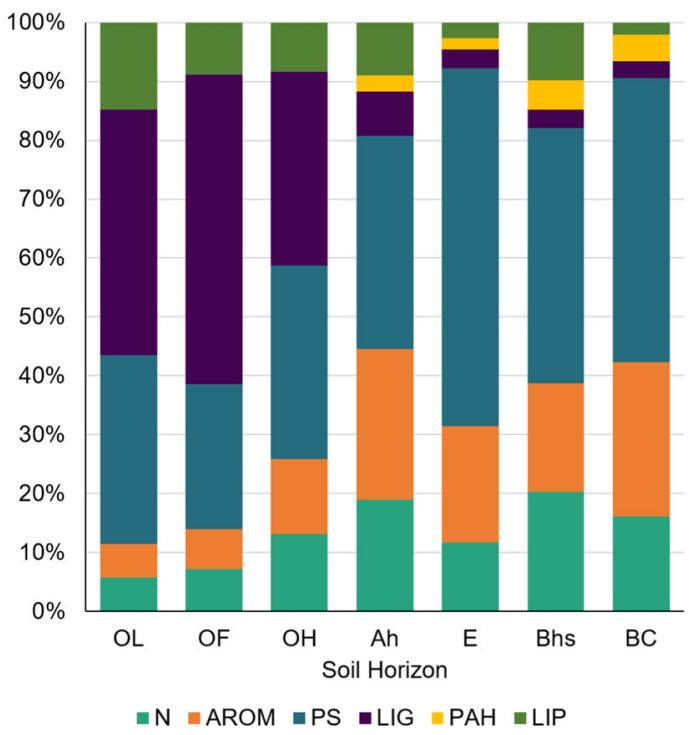

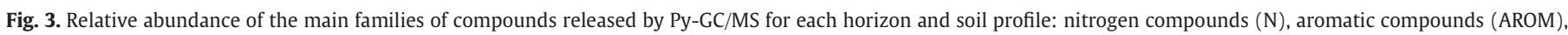
polysaccharides (PS), lignin-derived products (LIG), polycyclic aromatic hydrocarbons (PAH), and lipids (LIP). 
profile, the OL layer was enriched in aromatic compounds (22.9\%), which decreased to $7.47 \%$ in the $\mathrm{OH}$ layer. These results contrast the values obtained for the pine profile, where the $\mathrm{OH}$ layer was enriched (12.8\%) in aromatic compounds compared to the OL layer (5.83\%). The concentration of aromatic compounds in the $\mathrm{OH}$ layer of the pine profile may be related to a decrease in the lignin content, since some compounds that come from the degradation of lignin could be categorized as aromatic compounds (Ferro, 2010). Mineral Ah and E horizons showed similar relative abundances in both, the beech (26.6 and $19.9 \%$ ) and pine (25.6 and 19.8\%) profiles. The enrichment in aromatic compounds detected in the Bhs and $\mathrm{BC}$ horizons compared to the overlying horizons in both profiles could be a consequence of alkylphenol illuviation rather than in situ lignin degradation (Ferro, 2010), which is remarkably higher in the beech profile than in the pine profile.

Polycyclic aromatic hydrocarbons (PAH) were only detected in the mineral horizons, with a relative abundance ranging from 1.21 to $10.7 \%$ in the beech profile and from 1.90 to $4.93 \%$ in the pine profile (Fig. 3). The appearance of PAH has traditionally been identified as a product of the analytical pyrolysis of charred materials (GonzálezPérez et al., 2007; De la Rosa et al., 2008), which may be related to the occurrence of wildfires and/or charcoal production in the area. The higher PAH content detected in the Bhs horizons is probably related to the translocation from the uppermost horizons and later accumulation in the spodic horizon.

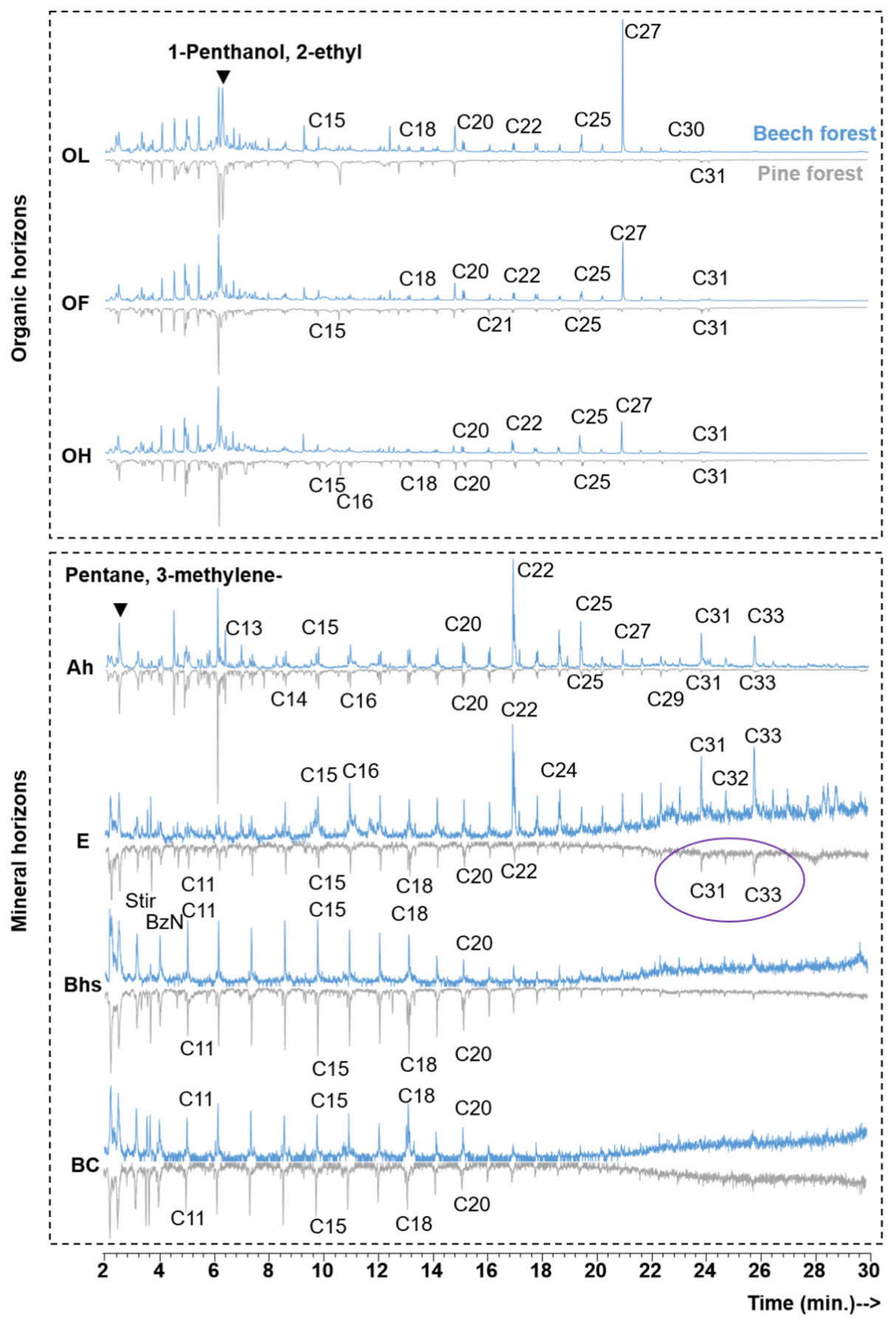

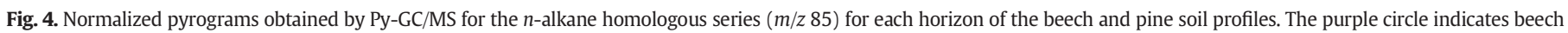
biomarkers found in the pine profile. (For interpretation of the references to colour in this figure legend, the reader is referred to the web version of this article.) 
The differences in the relative abundance of the lignin-derived pyrolysis products (methoxyphenols) were mainly detected in the organic layers, whereas their content remained similar in the mineral horizons (Fig. 3). The relative abundance of lignin compounds was higher in the $\mathrm{OH}$ layer of the beech profile $(57.9 \%)$ compared to the pine profile (32.8\%), whereas their values for the OL and OF layers were similar in both cases (ca. $50 \%$ of the total pyrolysis products). This higher lignin content in the beech organic layers compared to pine was previously observed in temperate forests (Vancampenhout et al., 2009). In the organic layers of the pine profile, a dominance of lignin compounds related to guaiacol was observed, which is a characteristic trait of gymnosperm softwood that was also detected in the Ah mineral horizon. On the other hand, in the beech profile, syringol-derived compounds were also detected, which is characteristic of angiosperm vegetation (Amelung et al., 2008).

The polysaccharide-derived fraction in the soil under beech increased progressively with depth from $18.0 \%$ in the OL layer to $59.0 \%$ in the E horizon, followed by a remarkable decrease in the Bhs (7.86\%) and $\mathrm{BC}(16.2 \%)$ horizons (Fig. 3). In the pine soil profile, the relative abundance of polysaccharides showed a similar trend as observed in the beech profile, increasing from the OL (31.9\%) to the $\mathrm{E}(60.8 \%)$ horizon, although no decrease was detected in the Bhs and BC horizons, where the abundance was still relatively high (43.4 and $48.3 \%$, respectively). The higher relative abundance of polysaccharide-derived fractions in the pine organic layer compared to those of the beech could be explained by the higher presence of microbial biomass observed in the pine profile. Fungal walls are composed of glycoproteins and polysaccharides, mainly glucan and chitin, which may explain the concomitant increase in the relative abundance of $\mathrm{N}$ and polysaccharide-derived compounds that were observed in deeper soil layers (Bhs and $\mathrm{BC}$ ) of the pine profile and are known products derived from the pyrolysis of chitin (Moldoveanu, 1998). Furthermore, the more abundant fraction of the polysaccharide-derived pyrolytic compounds for all horizons of both profiles corresponded to low molecular mass compounds such as furfural. This is related to the presence of small decomposed polysaccharides such as those of chitin biopolymers (Bowman and Free, 2006).

\subsection{Differences in the n-alkane series between forest types}

The study of the $n$-alkane $\left(\mathrm{C}_{n} \mathrm{H}_{2 n+2}\right)$ series allowed the detection of different vegetation markers in the soil related to each forest type (Fig. 4). Plants are known to preferentially produce odd-numbered carbon long chain alkanes (Eglinton et al., 1962), with the more prominent peaks detected in the pyrograms of samples from the organic layers. Since the distribution of long chain alkanes is a characteristic trait of the vegetation type, it can be used as a biomarker or molecular tracer for each of the forest species. However, as SOM undergoes transformations in the soil, this trend shifts, and usually, the proportion of short chain even-numbered carbon alkanes increases concomitantly with depth, as has been observed in previous works (González-Pérez et al., 2007; Amelung et al., 2008; Santana et al., 2015). Throughout the beech soil profile, the influence of vegetation was mainly reflected in the organic layers. As was previously observed using conventional biomarker approaches based on the study of soil lipid extracts, the $n$ alkane distribution in the organic layers under beech vegetation was dominated by the $C_{27}$ hydrocarbon, accompanied by variable amounts of $C_{25}$ that were substituted by shorter chain homologues $\left(C_{20}-C_{25}\right)$ in the mineral horizons (Marseille et al., 1999; Griepentrog et al., 2016). Additionally, a high proportion of long chain odd-numbered $n$-alkanes $\left(C_{31}-C_{33}\right)$ was found in the mineral soil samples. On the other hand, in the pine soil profile short-chained molecules $\left(<C_{20}\right)$ prevailed with no carbon number preference, which has been traditionally associated with products of microbial biosynthesis (Dinel et al., 1990; GonzálezPérez et al., 2012) and may indicate a higher degree of SOM degradation with contributions of organic compounds from the microbial biomass (Assis et al., 2011).
As stated above, the pyrograms of both the pine and beech profiles were clearly differentiated from the OL to Ah horizons. However, in the pine $E$ horizon an increase in the $C_{31}$ and $C_{33}$ peaks was detected, which was not observed in the overlying horizons. These $C_{31}$ and $C_{33}$ peaks were, although, detected in the Ah and $\mathrm{E}$ horizons of the beech profile, which suggested that these were biomarkers from the previous natural beech vegetation, which remained in the SOM for more than 100 years after the pine afforestation. Regarding the Bhs and $\mathrm{BC}$ mineral horizons of both forest types, a clear predominance of short chain $n$ alkanes and the disappearance of the $C_{31}$ and $C_{33}$ peaks was observed, suggesting the presence of a more evolved SOM at that depth.

These results match the findings of a previous study conducted in the same soil profiles that analyzed the SOM stable isotope composition, which indicated that SOM derived from the natural vegetation was still detectable in the $\mathrm{E}$ horizon of the afforested pine (Girona-García et al., 2018b).

\section{Conclusions}

Well-resolved chromatograms using Py-GC/MS were obtained for organic and mineral soil layers, and a total of 128 pyrolysis compounds were detected. The pyrograms showed the chemical variability of the SOM derived from the predominant vegetation type as well as its distribution down in the soil for each forest type. The SOM in organic soil layers (OL, OF and $\mathrm{OH}$ ) consisted mainly of lignocellulosic biomass with abundant lignin and polysaccharide derived compounds. The mineral horizons Ah and $\mathrm{E}$ were found to be particularly enriched in polysaccharides. The Bhs and BC horizons showed an increase in aromatic compounds, PAH and lipids, the latter being steeper in the beech soil, possibly due to microbial activity. An unexpectedly higher polysaccharide content was observed in the Bhs and BC horizons under pine, most likely related to the migration of complexed forms. The analytical pyrolysis results of selected ion traces for the $n$-alkane series $(\mathrm{m} / z$ 85) showed a higher abundance of odd-numbered carbon long chain alkanes in the beech compared to the pine profile indicating a greater stabilization of SOM. The appearance of probable beech biomarkers $\left(C_{31}\right.$ and $\mathrm{C}_{33}$ ) in the pine $\mathrm{E}$ horizon indicated the permanence of beechderived SOM ca. 100 years after the afforestation.

\section{Acknowledgments}

This study is part of the results of the FUEGONEO (CGL2016-76620R) and INTERCARBON (CGL2016-78937-R) projects funded by the Spanish "Ministerio de Economía y Competitividad". Girona-García, A. was funded by an FPI research grant (BES-2014-068072) of the "Ministerio de Economía y Competitividad" (Spanish government). Thanks are due for the financial support to CESAM (UID/AMB/50017 POCI-01-0145-FEDER-007638), to FCT/MCTES through national funds (PIDDAC), and the co-funding by the FEDER, within the PT2020 Partnership Agreement and Compete 2020. We also thank the Aragonese Agents for Nature Protection (APN) of the Moncayo Natural Park for their collaboration and for issuing the sampling permits.

\section{Appendix A. Supplementary data}

Supplementary data to this article can be found online at https://doi. org/10.1016/j.scitotenv.2019.07.229.

\section{References}

Almendros, G. Hernández, Z., Sanz, J., Rodríguez-Sánchez, S., Jiménez-González, M.A González-Pérez, J.A., 2018. Graphical statistical approach to soil organic matter resilience using analytical pyrolysis data. J. Chromatogr. A 1533, 164-173. https://doi.org/ 10.1016/j.chroma.2017.12.015.

Amelung, W., Brodowski, S., Sandhage-Hogmann, A., Bol, R., 2008. Chapter 6: Combining biomarker with stable isotope analyses for assessing the transformation and turnover of soil organic matter. Advances in Agronomy. 100, pp. 155-250. https://doi.org/ 10.1016/S0065-2113(08)00606-8. 
Assis, C.P., González-Vila, F.J., Jucksch, I., González-Pérez, J.A., Lima Neves, J.C., Lani, J.L., Sá Mendonça, E., 2011. Lipid abundance and composition of a humic Oxisol as a function of land use. Sci. Agric. 68 (2), 230-236. https://doi.org/10.1590/S010390162011000200014

Badia, D., Ruiz, A., Girona, A., Martí, C., Casanova, J., Ibarra, P., Zufiaurre, R., 2016. The influence of elevation on soil properties and forest litter in the siliceous Moncayo massif, SW Europe. J. Mt. Sci. 13, 2155-2169. https://doi.org/10.1007/s11629-015-3773-6.

Badia-Villas, D., Girona-García, A., 2018. Soil humus changes with elevation in Scots pine stands of the Moncayo Massif (NE Spain). Appl. Soil Ecol. 123, 617-621. https://doi. org/10.1016/j.apsoil.2017.07.017.

Binkley, D., 1995. The influence of tree species on forest soils: processes and patterns. In: Mead, D.J., Cornforth, I.S. (Eds.), P Ag Soc Nz 10. Lincoln University Press, Canterbury, pp. 1-33.

Bowman, S.M., Free, S.J., 2006. The structure and synthesis of the fungal cell wall. BioEssays 28, 799-808. https://doi.org/10.1002/bies.20441.

Buco, S., Moragues, M., Doument, P., Noor, A., Mille, G., 2004. Analysis of polycyclic aromatic hydrocarbons in contaminated soil by Curie point pyrolysis coupled to gas chromatography-mass spectrometry, an alternative to conventional methods. J. Chromatogr. 1026 (1-2), 223-229. https://doi.org/10.1016/j.chroma.2003.11.065.

De la Rosa, J.M., González-Pérez, J.A., González-Vázquez, R., Knicker, H., López-Capel, E., Manning, D.A.C., González-Vila, F.J., 2008. Use of pyrolysis/GC-MS combined with termal analysis to monitor $\mathrm{C}$ and $\mathrm{N}$ changes in soil organic matter from a Mediterranean fire affected forest. Catena 74, 296-303. https://doi.org/10.1016/j. catena.2008.03.004.

De la Rosa, J.M., Faria, S.R., Varela, M.E., Knicker, H., González-Vila, F.J., González-Pérez, J.A. Keizer, J., 2012. Characterization of wildfire effects on soil organic matter using analytical pyrolysis. Geoderma 191, 24-30. https://doi.org/10.1016/j. geoderma.2012.01.032.

Derenne, S., Quénéa, K., 2015. Analytical pyrolysis as a tool to probe soil organic matter. J. Anal. Appl. Pyrolysis 111, 108-120. https://doi.org/10.1016/j.jaap.2014.12.001.

Dinel, H., Schnitzer, M., Mehuys, G.R., 1990. In: Bollag, J.M., Stotzky, G. (Eds.), Soil lipids: origin, nature, contents, decomposition and effect on soil physical properties. Soil Biochemistry. Marcel Dekker, New York, pp. 397-427.

Eglinton, G., Hamilton, R.J., Raphael, R.A., González, A.G., 1962. Hydrocarbon constituents of the wax coatings of plant leaves: a taxonomic survey. Nature 193, 739-742.

Faria, S.R., De la Rosa, J.M. Knicker, H., González-Pérez J.A., Villaverde, J. Keizer, JJ. 2015. Wildfire-induced alterations of topsoil organic matter and their recovery in Mediterranean eucalypt stands detected with biogeochemical markers. Eur. J. Soil Sci. 66, 699-713. https://doi.org/10.1111/ejss.12254.

Ferro, C., 2010. Caracterización de la Podzolización en Ambiente Boreal Templado y Tropical y su Influencia en la Inmovilización de Metales (Al, Fe y Pb). PhD Dissertation. University of Santiago de Compostela, Spain.

García Manrique, E., 1960. Las Comarcas de Borja y Tarazona y el Somontano de Moncayo. Departamento de Geografía Aplicada del Instituto J.S. Elcano (CSIC) y la Institución "Fernando el Católico", Madrid.

Girona-García, A., Badía-Villas, D., Jiménez-Morillo, N.T., De la Rosa, J.M., González-Pérez J.A., 2018a. Soil C and N isotope composition after a centennial Scots pine afforestation in podzols of native European beech forests in NE-Spain. Catena 165, 434-441. https://doi.org/10.1016/j.catena.2018.02.023.

Girona-García, A., Badía-Villas, D., Martí, C., 2018b. Changes in topsoil properties after centennial Scots pine afforestation in a European beech forest (NE Spain). Forests 9, 343. https://doi.org/10.3390/f9060343.

González-Pérez, J.A., González-Vila, F.J., Almendros, G., Zancada, M.C., Polvillo, O., Martín F., 2003. Preferential accumulation of selectively-preserved macromolecular substances in the humus peat deposit as seen by analytical pyrolysis and spectroscopic techniques. J. Anal. Appl. Pyrolysis 68-69, 287-298. https://doi.org/10.1016/S01652370(03)00069-X

González-Pérez, J.A., Arbelo, C.D., González-Vila, F.F., Rodríguez Rodríguez, A., Almendros, G., Armas, C.M., Polvillo, O., 2007. Molecular features of organic matter in diagnostic horizons from andosols as seen by analitical pirolisis. J. Anal. Appl. Pyrolysis 80, 369-382.

González-Pérez, J.A., Chabbi, A., de la Rosa, J.M., Rumpel, C., González-Vila, F.J., 2012. Evolution of organic matter in lignite-containing sediments revealed by analytical pyrolysis (Py- GC/MS). Org. Geochem. 53, 119-130. https://doi.org/10.1016/j. jaap.2007.04.008

González-Vila, F.J., Almendros, G., Madrid, F., 1999. Molecular alterations of organic fractions from urban waste in the course of composting and their further transformation in amended soil. Sci. Total Environ. 236 (1-3), 215-229. https://doi.org/10.1016/ S0048-9697(99)00284-3.

González-Vila, F.J., González-Pérez, J.A., Akdi, K., Gómis, M.D., Pérez-Barrera, F., Verdejo, T. 2009. Assesing the efficiency or urban waste biocompostinG by analytical pyrolisys
(Py- GC/MS). Bioresour. Technol. 100 (3), 1304-1309. https://doi.org/10.1016/j. biortech.2008.06.067.

Griepentrog, M., Bodé, S., Boeckx, P., Wiesenberg, G.L.B., 2016. The fate of plant wax lipids in a model forest ecosystem under elevated $\mathrm{CO}_{2}$ concentration and increased nitrogen deposition. Org. Geochem. 98, 131-140. https://doi.org/10.1016/j. orggeochem.2016.05.005.

Ibarra, P., Echeverría, M.T., 2004. Relaciones clima, suelo y vegetación en la vertiente noreste del Moncayo. In: Peña Monné J.L, Longares Aladrén, LA Sánchez Fabre, M., Institución Fernando el Católico y Universidad de Zaragoza (Eds.), Geografía Física de Aragón. Aspectos Generales y Temáticos, pp. 199-212.

IPCC, 2014. Climate change 2014: Synthesis report. In: Core Writing Team Pachauri, R.K., Meyer, L.A. (Eds.), Contribution of Working Groups I, II and III to the Fifth Assessment Report of the Intergovernmental Panel on Climate Change. IPCC, Geneva, Switzerland.

IUSS Working Group WRB, 2014. World Reference Base for Soil Resources 2014. International soil classification system for naming soils and creating legends for soil maps. World Soil Resources Reports No. 106. FAO, Rome.

Jiménez-Morillo, N.T., De la Rosa, J.M., Waggoner, D., Almendros, G., González-Vila, F.J., González-Pérez, J.A., 2016. Fire effects in the molecular structure of soil organic matter fractions under Quercus suber cover. Catena 145, 266-273. https://doi.org/ 10.1016/j.catena.2016.06.022.

Kögel-Knabner, I., Ekschmitt, K., Flessa, H., Guggenberger, G., Matzner, E., Marschner, B., von Lützow, M., 2008. An integrative approach of organic matter stabilization in temperate soils: linking chemistry, physics, and biology. J. Plant Nutr. Soil Sci. 171, 5-13. https://doi.org/10.1002/jpln.200700215

Labaz, B., Galka, B., Bogacz, A., Waroszewski, J., Kabala, C., 2014. Factors influencing humus forms and forest litter properties in the mid-mountains under temperate cli- mate of Southwestern Poland. Geoderma 230-231, 265-273. https://doi.org/10.1016/j. geoderma.2014.04.021.

Leuschner, C., Wulf, M., Bäuchler, P., Hertel, D, 2013. Soil C and nutrient stores under Scots pine afforestations compared to ancient beech forests in the German Pleistocene: the role of tree species and forest history. For. Ecol. Manag. 310, 405-415. https://doi.org/10.1016/j.foreco.2013.08.043.

Marseille, F., Disnar, J.R., Guillet, B., Noack, Y., 1999. n-alkanes and free fatty acids in humus and A1 horizons of soils under beech, spruce and grass in the MassifCentral (Mont-Lozère), France. Eur. J. Soil Sci. 50, 433-441. https://doi.org/10.1046/ j.1365-2389.1999.00243.x.

Martínez del Castillo, E., Serrano-Notivoli, R., Novak, K., Longares Aladrén, L.A., Arrechea, E., de Luis Arrillaga, M., Saz Sánchez, M.A., 2012. Cuantificación de los gradientes climáticos altitudinales en la vertiente norte del Macizo del Moncayo a partir de una nueva red de estaciones automáticas en altura. In: Rodríguez Puebla, C. Ceballos Barbancho, A., Gonzalez Reviriego, N., Moran Tejeda, E., Hernandez Encinas, A. (Eds.), Cambio Climático: Extremos e impactos, pp. 519-528.

Marty, C. Houle, D. Gagnon, C. Duchesne, L, 2011. Isotopic compositions of S, N and C in soils and vegetation of three forest types in Québec, Canada. J. Appl. Geochem. 26, 2181-2190. https://doi.org/10.1016/j.apgeochem.2011.08.002.

Miralles, I., Piedra-Buena, A., Almendros, G., González-Vila, F.J., Delgado Clavo-Flores, R., González-Pérez, J.A., 2015. Pyrolytic appraisal of the lignin signature in soil humic acids: assessment of its usefulness as carbon sequestration marker. J. Anal. Appl. Pyrolysis 113, 107-115. https://doi.org/10.1016/j.jaap.2014.11.010.

Moldoveanu, S.C., 1998. Analytical Pyrolysis of Natural Organic Polymers, Techniques and Instrumentation in Analytical Chemistry 20Rumpel 2012.

Santana, G.S., Knicker, H., González-Vila, F.J., González-Pérez, J.A., Pinheiro Dick, D., 2015. The impact of exotic forest plantations on the chemical composition of soil organic matter in Southern Brazil as assessed by Py-GC/MS and lipid extracts study. Geoderma Reg. 4, 11-19. https://doi.org/10.1016/j.geodrs.2014.11.004

Rumpel, C., Rodríguez-Rodríguez, A., González-Pérez, J.A., Arbelo, C., Chabbi, A., Nunan, N., González-Vila, F.J., 2012. Contrasting composition of free and mineral-bound organic matter in top- and subsoil horizons of Andosols. Biol. Fertil. Soils 48, 401-411. https:// doi.org/10.1007/s00374-011-0635-4

SSS, Soil Survey Staff, 2014. Keys to Soil Taxonomy. 12th edition. USDA-NRCS, Washington.

Vancampenhout, K., Wouters, K., De Vos, B., Buurman, P., Swennen, R., Deckers, J., 2009. Differences in chemical composition of soil organic matter in natural ecosystems from different climatic regions - a pyrolysis-GC/MS study. Soil Biol. Biochem. 41, 568-579. https://doi.org/10.1016/j.soilbio.2008.12.023.

Weil, R.R., Brady, N.C., 2017. The Nature and Properties of Soils. fifteenth ed. Pearson, Harlow, England (1104 pp. ISBN: 978-0-13-325448-8)

White, D.M., Garland, D.S., Beyer, L., Yoshikawa, K., 2004. Pyrolysis-GC/MS fingerprinting of environmental samples. J. Anal. Appl. Pyrolysis 71, 107-118. https://doi.org/ 10.1016/S0165-2370(03)00101-3. 